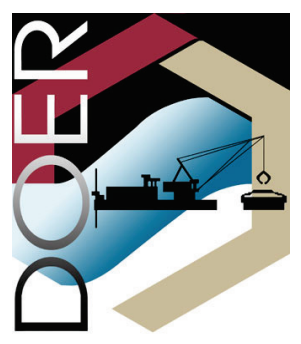

ERDC TN-DOER-R25

February 2017

\title{
Application of Toxicity Identification and Evaluation Procedures for Dredged Material Management
}

\author{
by Joseph P. Kreitinger, J. Daniel Farrar, and Guilherme R. Lotufo
}

PURPOSE: Federal regulatory statutes and guidance require the U.S. Army Corps of Engineers (USACE) to evaluate direct, indirect, and cumulative environmental impacts associated with management of dredged material including the potential for release of contaminants at disposal sites [1]. As limitations to the placement of dredge material in confined disposal facilities (CDF) increase, the development of sustainable alternatives for dredged material management are being pursued. However, the evaluation of potential environmental impacts that may result from alternative management strategies, such as the beneficial use of dredged material for shoreline habitat restoration, urban brownfield site redevelopment, and the restoration of agricultural and forest lands, is often complex. The evaluation of environmental impacts from these alternative management strategies typically requires more data than the assessment of risks associated with placement of dredged material in a CDF.

The USACE Inland Testing Manual and Ocean Disposal Manual provide guidance on a tiered effects-based testing framework that is used to establish the acceptability of placing dredged materials in open water and near-shore environments [2,3]. The effects-based testing relies on standard toxicity tests using freshwater and marine organisms for assessing the potential toxicity of dredged materials. However, these methods provide little or no information on the agents causing toxicity. This additional information (i.e., understanding the mechanism or cause of toxicity) is a critical component for the evaluation of environmental impacts that are associated with many alternative dredged material management options.

The lack of an approach for obtaining information on the source of toxicity when conducting standard toxicity tests, resulted in the U.S. Environmental Protection Agency (EPA) developing a new class of testing protocols referred to as Toxicity Identification and Evaluation (TIE) methods. The USACE is currently evaluating these new TIE methods for whole sediments and interstitial sediment pore waters for application to dredged material management. The following technical note provides background on TIE procedures, their use within the multi-step dredged material evaluation process, and their application to decision-making under the Upland Testing, Inland Testing, and Ocean Disposal Manuals [1-3].

BACKGROUND: Dredged material created during the maintenance of urban and industrial navigation channels often contains trace levels of contaminants that may pose a risk to human health and the environment. The potential for risk ultimately depends on the final disposition of the dredged material and potential for exposure to humans or ecological receptors. The Inland Testing and Ocean Disposal Manuals establish a multi-step testing protocol designed to assess the potential for toxicity to aquatic life. Laboratory bioassays are conducted using aquatic macroinvertebrates and fish. If toxicity is observed in laboratory tests, it is likely that the 
contaminants present at concentrations exceeding Sediment Quality Guidelines (SQGs) are the source of toxicity [4]. However, SQGs are only approximate guidelines for the concentration at which toxicity may occur and are not definitive indictors of toxicity.

While the application of toxicity testing may be adequate for establishing that no significant environmental impacts are likely to result from dredging operations and maintenance, cost effective engineering, design, and management of contaminated dredged materials require information on the source of potential toxicity. For example, laboratory testing for toxicity of sediments collected from various harbors in the Great Lakes have shown that ammonia is often a predominant source of the toxicity [5,6]. However, the selection of cost effective and sustainable alternatives for dredged material management would clearly be different if ammonia is identified as the source of toxicity as opposed to lead, mercury, or polychlorinated biphenyls (PCBs). The presence of high concentrations of ammonia would be a positive characteristic of the dredged material when contemplating its use for revegetation of an upland urban brownfield site.

As shown in Figure 1, understanding the causative agents of toxicity is important for the cost effective management of dredged materials. Cost effective engineering and construction of caps and liners to contain contaminants can only be accomplished if the environmental processes affecting contaminant fate and transport are understood. For example, the thickness of a cap required to contain polycyclic aromatic hydrocarbons (PAHs) within a confined aquatic disposal (CAD) facility may only be a few inches, whereas the cap thickness required to contain methyl mercury may be several feet.

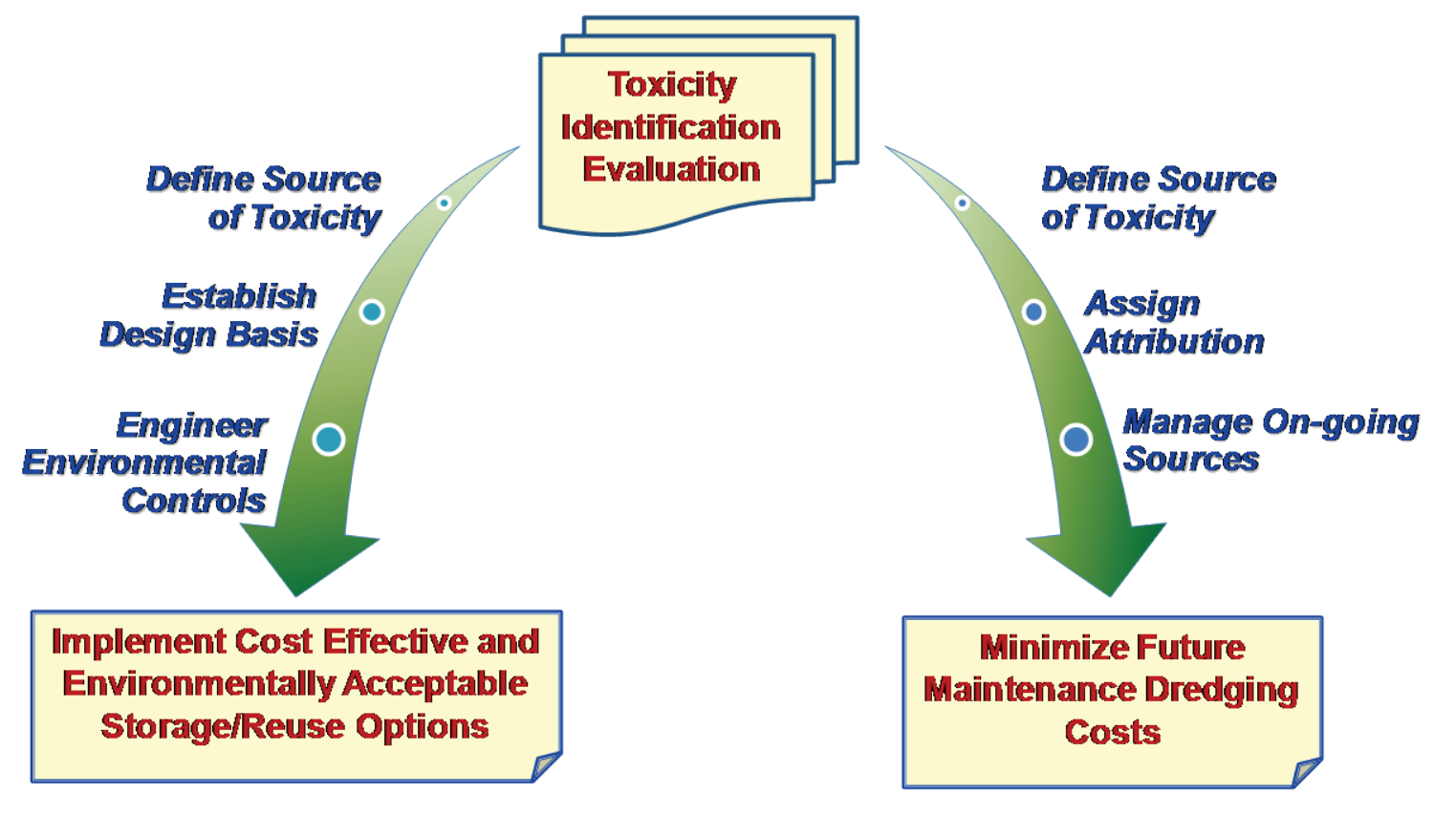

Figure 1. Using TIE Procedures to Reduce Dredged Material Management Costs. 
In the future, the costs associated with operation and maintenance of navigation channels will increasingly be a function of the restriction on the beneficial uses of dredged materials. In addition, identifying sources of contamination improves the linkage between agents causing toxicity, thereby increasing costs for dredged material management and responsible parties. The USACE is uniquely positioned to establish the environmental costs related to maintenance of federal navigation channels that are the result of continuing sources of harbor pollution. Knowing the specific chemical(s) causing sediment toxicity will enable resource managers and regulatory agencies to focus on policy and remedial actions that reduce environmental degradation and cost to maintain navigation channels in the nation's waterways.

TOXICITY IDENTIFICATION AND EVALUATION (TIE) PROCEDURE: TIE procedures have been developed for whole sediment, sediment porewater, or sediment elutriate samples. The procedures rely upon standard toxicity testing methods that include physical or chemical manipulations of the sample that are designed to elucidate the cause(s) of toxicity. TIE procedures have been categorized into three similar but functionally different testing phases (Table 1). The three phases are as follows: (1) characterize the nature of the toxicity into several classes (e.g., metal, organic compounds, and ammonia), (2) identify the specific toxicants responsible for the observed adverse effects, and (3) confirm the identity of chemical(s) causing toxicity.

\begin{tabular}{||}
\hline \hline $\begin{array}{l}\text { Table 1. Toxicity Identification and Evaluation (TIE) } \\
\text { Procedures. }\end{array}$ \\
\hline \hline - Phase I & $\begin{array}{l}\text { Characterize the nature of the toxicity into } \\
\text { several classes (e.g. metal, organic } \\
\text { compounds, and ammonia ) }\end{array}$ \\
\hline - Phase II & $\begin{array}{l}\text { Identify the specific toxicants responsible } \\
\text { for the adverse effects observed }\end{array}$ \\
\hline - Phase III & $\begin{array}{l}\text { Confirm the identity of chemical(s) causing } \\
\text { toxicity determined in the first two phases of } \\
\text { testing }\end{array}$ \\
\hline
\end{tabular}

a. Phase I. Phase I TIE testing uses amendments added to the test sediment or water that remove or alter the bioavailability of specific classes of contaminants. By comparing the toxicity of samples before and after chemical/physical manipulations, Phase I TIE procedures are intended to steer the TIE investigation toward general classes of possible toxicants as shown in Figure 2.

b. Phase II. Phase II TIE testing is intended to identify specific toxicants within the different classes of compounds characterized in Phase I. A wide variety of testing procedures can be used to help establish the identity of specific toxicants. Applicable testing procedures include measuring the change in sediment toxicity with changes in temperature or $\mathrm{pH}$, observing differences in species sensitivity, or adding other amendments such as enzymes, sorbents, or other chemicals that are specifically designed to either increase or decrease the toxicity of a target chemical as described in Table 2. In addition, chemicals extracted from toxic sediments onto semi-permeable membrane devices (SPMDs) or other solid phase sorbents can be used to preferentially spike contaminants into Phase II toxicity tests by reverse phase extraction techniques [8]. 


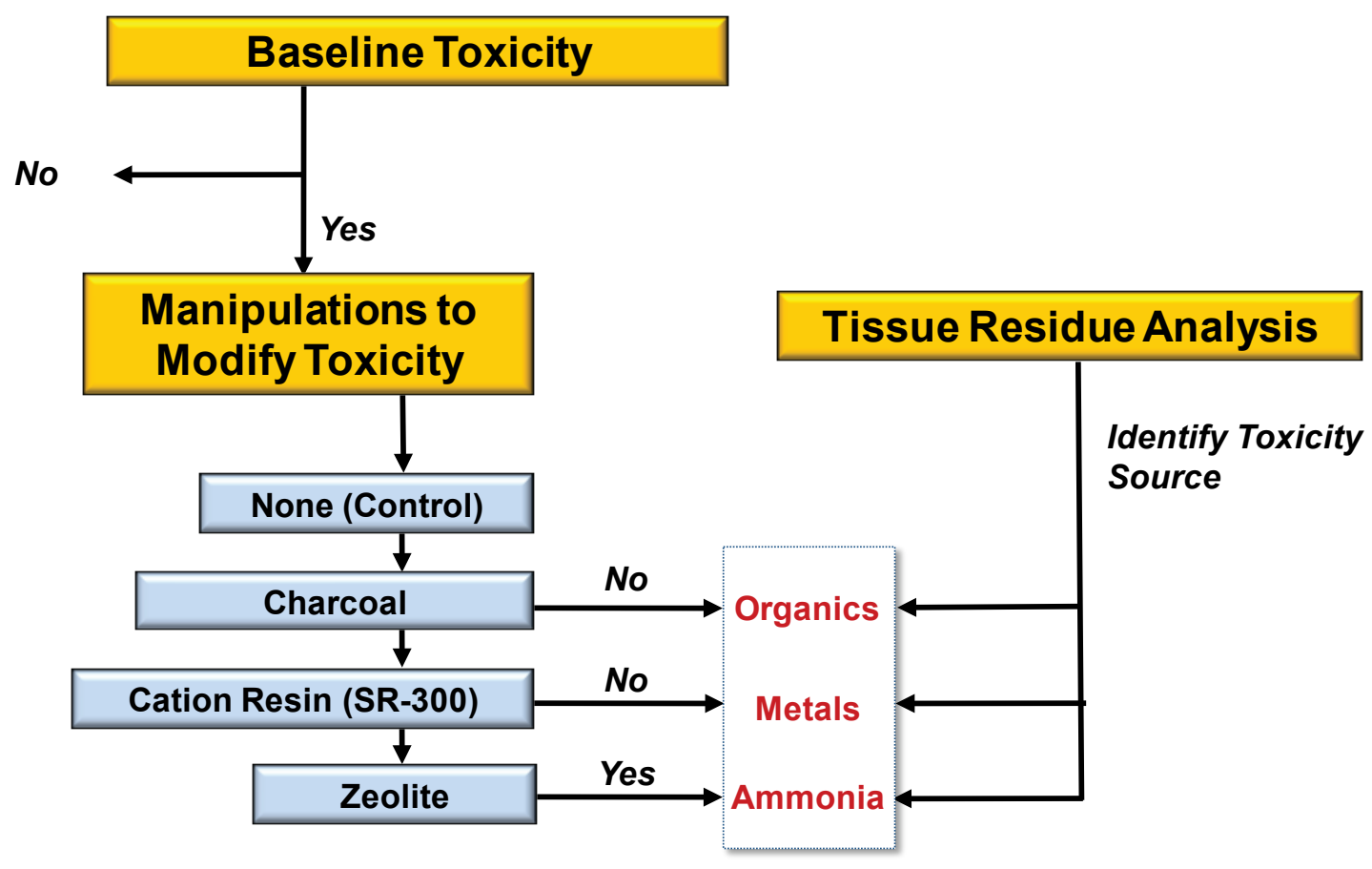

Figure 2. Toxicity Identification Evaluation (TIE) Procedures Incorporating Analysis of Tissue Residues.

A causal relationship for the toxicity observed in aquatic environments (or laboratory samples) and the source of toxicity is often difficult to prove. Phase II testing uses a weight of evidence approach where the number and type of tests required is dependent on the weight of evidence needed to make a decision. Typically, Phase II data identifies and quantifies the concentrations of the presumptive, causative toxicant(s) using chemical analysis, as well as developing a suite of biological responses from specific tests that are consistent with the proposed toxicant(s). One simple approach for developing Phase II data is to conduct chemical analysis of biota tissue following laboratory toxicity tests for any suspected toxicants that are not readily metabolized and may bioaccumulate in the test organism (Figure 2).

The USACE Environmental Laboratory is currently evaluating the application of recently developed microscale methods for detection of PCBs and PAHs in small tissue samples in Phase II TIE testing [9]. The weight of evidence necessary to sufficiently identify the causal agents responsible for the observed toxicity and the characterization of risk will vary depending upon the decisions made using this information and their environmental, economic, and social impact. For example, decisions regarding the feasibility of using dredged material beneficially for recreating shoreline habitat for a threatened and endangered species may have a higher certainty requirement than for developing a monitoring program for a confined aquatic disposal facility. The weight of the evidence developed by a TIE should be proportional to the weight of the decision. The amount of evidence generally 
considered reasonable to identify a toxicant is two separate manipulations pointing toward the same toxicant with a lack of evidence to the contrary, combined with chemical analysis demonstrating the presence of the toxicant at concentrations that could result in the observed toxicity [7].

\begin{tabular}{|c|c|c|c|}
\hline Target Toxicant & Test Manipulation & Effect & Reference \\
\hline $\begin{array}{l}\text { Non-ionic Organic } \\
\text { Compounds } \\
\text { - PAHs } \\
\text { - PCBs } \\
\text { - } \text { Chlorinated } \\
\text { pesticides }\end{array}$ & $\begin{array}{l}\text { - Coconut charcoal } \\
\text { - Amberlite XAD-4 resin } \\
\text { - C18 resin } \\
\text { - Dowex L493 resin } \\
\text { - Ultraviolet Light } \\
\text { - Reverse polyethylene } \\
\text { - samplers } \\
\text { - Bioaccumulation } \\
\text { Analysis } \\
\text { - Comet assay }\end{array}$ & $\begin{array}{l}\text { - Reduce toxicity } \\
\text { - Preferentially extract } \\
\text { nonpolar organic } \\
\text { compounds for } \\
\text { analysis } \\
\text { - Enhance phototoxicity } \\
\text { - Preferentially extract } \\
\text { and dose test } \\
\text { organisms } \\
\text { - Measure toxicant in } \\
\text { organism } \\
\text { - Measure DNA damage }\end{array}$ & {$[8,10-15]$} \\
\hline $\begin{array}{l}\text { Pyrethroid and } \\
\text { Organophosphate } \\
\text { Pesticides } \\
\text { - Bifenthrin, } \\
\text { - Cyfluthrin } \\
\text { - Cypermethrin } \\
\text { - Chlorpyrifos }\end{array}$ & $\begin{array}{l}\text { - Temperature } \\
\text { - Carboxylesterase and } \\
\text { phosphotriesterase } \\
\text { Enzymes } \\
\text { - Piperonyl butoxide } \\
\text { (PBO) }\end{array}$ & $\begin{array}{l}\text { - Reduce/increase } \\
\text { toxicityl } \\
\text { - Metabolic inhibition of } \\
\text { pesticide detoxification } \\
\text { increasing toxicity }\end{array}$ & [16-20] \\
\hline $\begin{array}{l}\text { Cationic Metals } \\
\text { - Cadmium } \\
\text { - Chromium } \\
\text { - Copper } \\
\text { - Iron } \\
\text { - Lead } \\
\text { - Silver } \\
\text { - Zinc }\end{array}$ & $\begin{array}{l}\text { - SIR-300 resin } \\
\text { - EDTA } \\
\text { - CM resin }\end{array}$ & $\begin{array}{l}\text { - Reduce Toxicity } \\
\text { - Preferentially extract } \\
\text { metals for analysis } \\
\text { - Organic chelate for } \\
\text { divalent metals that } \\
\text { binds and reduces } \\
\text { toxicity }\end{array}$ & {$[12,14,15,21,22]$} \\
\hline $\begin{array}{l}\text { Anionic Metals } \\
\text { - Arsenic } \\
\text { - Chromium }\end{array}$ & $\begin{array}{l}\text { - SBMP1-TR resin } \\
\text { - WBMP-HP resin } \\
\text { - SIR } 700 \text { resin } \\
\text { - } \text { ASM-10-HP resin } \\
\text { - } \text { QMA-resin } \\
\end{array}$ & - Reduce Toxicity & {$[12,23]$} \\
\hline Ammonia & $\begin{array}{l}\text { - Zeolite } \\
\text { - Ulva lactuca } \\
\text { - Aeration } \\
\text { - Graduated pH }\end{array}$ & $\begin{array}{l}\text { - Reduce toxicity } \\
\text { - Increase toxicity }\end{array}$ & {$[13,15,22,24-26]$} \\
\hline $\begin{array}{l}\text { Sulfides and Organic } \\
\text { Acids }\end{array}$ & 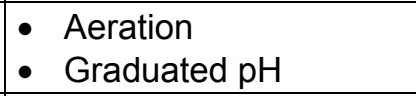 & $\begin{array}{l}\text { - Reduce/Increase } \\
\text { toxicity }\end{array}$ & {$[15,22]$} \\
\hline $\begin{array}{l}\text { Oxidizing Agents } \\
\text { - Chlorine, } \\
\text { - Bromine } \\
\end{array}$ & - Sodium thiosulfate & - Chemical reduction & [15] \\
\hline
\end{tabular}


c. Phase III. The objective of Phase III TIE testing is to confirm the identity of the suspected toxicant(s) identified in Phase II. Confirmation of the source of toxicity may take several different approaches including testing to confirm that the identified toxicant(s) is consistent with the toxicity observed in samples collected from other locations or in samples collected at different times. For example, Phase III testing may be warranted if toxicity from a specific contaminant was identified in sediment samples conducted several years earlier. In addition to confirming the source of toxicity over time or between locations, Phase III TIE testing may be used to confirm whether the toxicant observed in laboratory tests is the same as the toxicant responsible for the adverse effects observed in the field [13]. For some compounds, preliminary testing may identify a toxicant when interstitial water or elutriates samples are used as the test matrix; however, toxicity is not observed when bulk sediment samples are tested. For example, studies have shown that toxicity may be present in porewater or elutriate TIE tests; however, toxicity is not present in whole sediment tests [7, 27].

LIMITATIONS: The ability to identify the source of toxicity is relatively easy when common pollutants such as PCBs, PAHs, pesticides, and metals are responsible for the observed toxicity. However, the presence of unusual toxicants or biological factors, both manufactured and naturally occurring, can be very difficult to identify and confirm. There are a number of naturally occurring environmental toxicants in aquatic environments, such as organic acids from the anaerobic metabolism of organic matter and microcystin produced by harmful algal blooms, which may result in toxicity to macroinvertebrates or wildlife [28].

Many of the limitations of TIEs are those inherent in conducting toxicity tests for the evaluation of dredged material toxicity.

- Test Organism Selection. The selection of toxicity test organisms is important since the toxic response observed in the laboratory ultimately needs to be extrapolated to the potential response of biota in the field. Ecological relevance of the laboratory tests must be considered in the development and interpretation of TIE procedures. Although TIE testing may be correctly performed and identify the source of toxicity in a laboratory toxicity test, the conclusion that the same source of toxicity exists in the field may be incorrect if the organism being tested is irrelevant to the biological community in the field. Approaches to link the results of toxicity tests performed in the laboratory to measurements of effects in the field have included conducting in situ toxicity tests and TIE manipulations in the field, as well as, conducting surveys and analysis of field collected organisms $[11,13]$.

- Measurement Endpoints. Growth and reproduction measurements for chronic toxicity tests are often much more variable than measurements of survival or mortality. Often there is not enough statistical power to evaluate whether differences exist in chronic toxicity endpoints between TIE manipulations. The TIE procedures currently developed are best suited for assessment of test organism survival or mortality in acute toxicity tests.

- Discrimination Between Contaminants Having Similar Physical/Chemical Characteristics. Identifying the source of toxicity in contaminant mixtures is difficult, especially when the contaminants have similar physical and chemical characteristics. For example, identifying whether toxicity is related to a fuel oil spill or pyrogenic hydrocarbons originating from storm sewer outfalls is challenging. Procedures to help identify the source 
of toxicity include direct analysis of contaminants present in test organism tissues, as well as looking for biochemical markers of contaminant metabolism.

CONCLUSION: According to federal regulatory statutes and guidance, the USACE is required to evaluate direct, indirect, and cumulative environmental impacts associated with managing dredged material including the potential for release of contaminants at disposal sites.

As limitations to the placement of dredged material in CDFs increase and the development of sustainable alternatives for dredged material management are pursued, the evaluation of potential environmental impacts becomes more complex. Assessment of environmental impacts from the beneficial uses of dredged material and the design of engineered systems for managing the risk of contaminated dredged materials require additional data that includes information on the sources of potential toxicity to human health and ecological receptors. This information is also useful when evaluating dredged material for open water disposal since it could eliminate or support the assignment of toxicity to non-contaminant factors. TIEs are a tool that fit within the tiered effectsbased testing developed under the Inland Testing Manual and Ocean Disposal Manual.

POINT OF CONTACT: For additional information, contact Mr. J. Daniel Farrar (601-6342118)Daniel.Farrar@usace.army.mil.

This technical note should be cited as follows:

Kreitinger, J.P., J. D. Farrar, G.R. Lotufo and G. R. Lotufo. 2017. Application of Toxicity Identification and Evaluation Procedures for Dredged Material Management. DOER Technical Notes Collection (ERDC TN-DOER-R25). Vicksburg, MS: U.S. Army Engineer Research and Development Center. http://el.erdc.usace.army.mill.

\section{REFERENCES}

Amweg, E. L., and D. P. Weston. 2007. Whole-sediment toxicity identification evaluation tools for pyrethroid insecticides: I. Piperonyl butoxide addition. Environmental Toxicology and Chemistry 26:2389-2396.

Ankley, G. T., A. Katko, and J. W. Arthur. 1990. Identification of ammonia as an important sediment-associated toxicant in the lower Fox River and Green Bay, Wisconsin. Environmental Toxicology and Chemistry 9:313322.

Ankley, G. T., M. K. Schubauer-Berigan, and J. R. Dierkes. 1996. Application of toxicity identification evaluation techniques to pore water from Buffalo River sediments. Journal of Great Lakes Research 22:534-544.

Besser, J. M., C. G. Ingersoll, E. N. Leonard, and D. R. Mount. 1998. Effect of zeolite on toxicity of ammonia in freshwater sediments: Implications for toxicity identification evaluation procedures. Environmental Toxicology and Chemistry 17:2310-2317.

Burgess, R. M., M. G. Cantwell, M. C. Pelletier, K. T. Ho, J. R. Serbst, H. F. Cook, and A. Kuhn. 2000. Development of a toxicity identification evaluation procedure for characterizing metal toxicity in marine sediments. Environmental Toxicology and Chemistry 19:982-991.

Burgess, R. M., M. C. Pelletier, K. T. Ho, J. R. Serbst, S. A. Ryba, A. Kuhn, M. M. Perron, P. Raczelowski, and M. G. Cantwell. 2003. Removal of ammonia toxicity in marine sediment TIEs: a comparison of Ulva lactuca, zeolite and aeration methods. Marine Pollution Bulletin 46:607-618. 


\section{ERDC TN-DOER-R25}

\section{February 2017}

Burgess, R. M., M. M. Perron, M. G. Cantwell, K. T. Ho, J. R. Serbst, and M. C. Pelletier. 2004. Use of zeolite for removing ammonia and ammonia-caused toxicity in marine toxicity identification evaluations. Archives of Environmental Contamination and Toxicology 47:440-447.

Burgess, R. M., M. M. Perron, M. G. Cantwell, K. T. Ho, M. C. Pelletier, J. R. Serbst, and S. A. Ryba. 2007. Marine sediment toxicity identification evaluation methods for the anionic metals arsenic and chromium. Environmental Toxicology and Chemistry 26:61-67.

Carr, R. S., M. Nipper, J. M. Biedenbach, R. L. Hooten, K. Miller, and S. Saepoff. 2001. Sediment toxicity identification evaluation (TIE) studies at marine sites suspected of ordnance contamination. Archives of Environmental Contamination and Toxicology 41:298-307.

Custer, K. W., and G. A. Burton. 2008. Isonychia spp. and macroinvertebrate community responses to stressors in streams utilizing the benthic in situ toxicity identification evaluation (BiTIE) method. Environmental Pollution 151:101-109.

Fjallborg, B., B. Li, E. Nilsson, and G. Dave. 2006. Toxicity identification evaluation of five metals performed with two organisms (Daphnia magna and Lactuca sativa). Archives of Environmental Contamination and Toxicology 50:196-204.

Harwood, A. D., J. You, and M. J. Lydy. 2009. Temperature as a toxicity identification evaluation tool for pyrethroid insecticides: Toxicokinetic confirmation. Environmental Toxicology and Chemistry 28:1051-1058.

Ho, K. T., M. L. Gielazyn, M. C. Pelletier, R. M. Burgess, M. C. Cantwell, M. M. Perron, J. R. Serbst, and R. L. Johnson. 2009. Do toxicity identification and evaluation laboratory-based methods reflect causes of field impairment? Environmental Science \& Technology 43:6857-6863.

Hunt, J., B. Anderson, B. Philips, R. Tjeerdema, B. Largay, M. Beretti, and A. Bern. 2008. Use of toxicity identification evaluations to determine the pesticide mitigation effectiveness of on-farm vegetated treatment systems. Environmental Pollution 156:348-358.

Kay, D. P., J. L. Newsted, M. T. BenKinney, T. J. Lannuzzi, and J. P. Giesy. 2008. Passaic River sediment interstitial water phase I toxicity identification evaluation. Chemosphere 70:1737-1747.

Mahler, W. T., J. You, J. D. Maul, and M. J. Lydy. 2010. Comparative analysis of whole sediment and porewater toxicity identification evaluation techniques for ammonia and non-polar organic contaminants. Chemosphere $78: 814$

Millward, R., R. Jones, K. Karn, and A. Harrison. 2007. A Microscale Approach for the Quantitative Detection of $P C B s$ and PAHs in Small Tissue Masses. ERDC TN-DOER-T9. Vicksburg, MS: U.S. Army Engineer Research and Development Center.

Montagnolli, W., A. Zamboni, R Luvizotto-Santos, and J. S. Yunes. 2004. Acute Effects of Microcystis aeruginosa from the Patos Lagoon Estuary, Southern Brazil, on the Microcrustacean Kalliapseudes schubartii (Crustacea: Tanaidacea). Archives of Environmental Contamination and Toxicology 46:463-469.

Perron, M. M., R. M. Burgess, K. T. Ho, M. C. Pelletier, C. L. Friedman, M. G. Cantwell, and J. P. Shine. 2009. Development and evaluation of reverse polyethylene samplers for marine Phase II whole-sediment toxicity identification evaluations. Environmental Toxicology and Chemistry 28:749-758.

Phillips, B. M., B. S. Anderson, J. W. Hunt, S. L. Clark, J. P. Voorhees, R. S. Tjeerdema, J. Casteline, and M. Stewart. 2009. Evaluation of phase II toxicity identification evaluation methods for freshwater whole sediment and interstitial water. Chemosphere 74:648-653.

Stronkhorst, J., M. E. Schot, M. C. Dubbeldam, and K. T. Ho. 2003. A toxicity identification evaluation of silty marine harbor sediments to characterize persistent and non-persistent constituents. Marine Pollution Bulletin 46:56-64. 
U.S. Army Corps of Engineers. 1998. Use of sediment quality guidelines (SQGs) in dredged material management decision-making. Memo from Director of Civil Works (Russell L. Fuhrman, Major General), to: Commander, CECW-OD. October 12.

U.S. Army Corps of Engineers. 2003. Evaluation of Dredged Material Proposed for Disposal at Island, Nearshore, or Upland Confined Disposal Facilities - Testing Manual. ERDC/EL TR-03-1. Vicksburg, MS: U.S. Army Engineer Research and Development Center.

U.S. Environmental Protection Agency, U.S. Army Corps of Engineers. 1991. Evaluation of Dredged Material Proposed for Ocean Disposal. - Testing Manual. EPA-503/8-91/001. Washington, DC.

U.S. Environmental Protection Agency, U.S. Army Corps of Engineers. 1998. Evaluation of Dredged Material Proposed for Disposal in Waters of the U.S. - Testing manual. EPA-823-B-004. Washington, DC.

U.S. Environmental Protection Agency. 2007. Sediment Toxicity Identification Evaluation (TIE) Phases I, II, and III Guidance Document. EPA/600/R-07/080. Washington, DC: Office of Research and Development.

Weston, D. P., and C. J. Jackson. 2009. Use of engineered enzymes to identify organophosphate and pyrethroidrelated toxicity in toxicity identification evaluations. Environmental Science \& Technology 43:5514-5520.

Weston, D. P., J. You, A. D. Harwood, and M. J. Lydy. 2009. Whole sediment toxicity identification evaluation tools for pyrethroid insecticides: III. Temperature manipulation. Environmental Toxicology and Chemistry 28:173-180.

NOTE: The contents of this technical note are not to be used for advertising, publication, or promotional purposes. Citation of trade names does not constitute an official endorsement or approval of the use of such products. 